\title{
A STUDY ON SOLUBILIZATION OF EXCESS SLUDGE BY HIGH SPEED ROTARY DISK PROCESS
}

\author{
T. Imai*, M. Fukagawa**, M. Ukita*, M. Sekine*, T. Higuchi*, and T. Kawamura** \\ * Dept. of Civil Engineering, Yamaguchi University, Tokiwadai, Ube, Yamaguchi 755-8611, JAPAN \\ ** Ube National College of Technology, Tokiwadai, Ube, Yamaguchi 755-8555, JAPAN
}

\begin{abstract}
This study describes the solubilization of excess sludge by high speed rotary disk process. The excess sludge from final sedimentation tank in wastewater treatment plant was used in this study. The experiments of sludge through the high speed rotary disk were carried out. The results indicated that it was possible to improve the solubilization of excess sludge by this treatment process. Significant decrease of particle size after first time treatment was observed. With the increase of recycle time of treatment, the solubilization was obviously improved. It was suggested that the solubilization of microorganisms due to the function of hydrolase from broken microbial cell was promoted.
\end{abstract}

\section{KEYWORDS}

Solubilization; excess sludge; high speed rotary disk process; biodegradability; organic solid waste; hydrolase

\section{INTRODUCTION}

The consumption of resources and energy based on human activities followed by huge amount of wastes has being one of the most serious problems all over the world. It leads to terrible destruction of the global or regional environment, and its negative effects on human being's health as well as global ecosystem are appearing evidently. It is therefore necessary to establish the effective technology, i.e., prevention of emissions and saving resources and energy.

Recently, approximately 1.7 million tons of sludge (as dry weight) are discharged on an annual basis. In Japan, where space is quite limited, volume reduction technology based on incineration was started at an early stage due to the difficulty of obtaining landfill space. Currently, approximate $60 \%$ of sludge is incinerated. On the other hand, effective use of sludge through composting, energy recovery by anaerobic digestion and other technology are pretty low (about 15\%), such uses are the focus of intensive study. The reason for this is that construction costs and operating costs related to incineration-based treatment are predicted to rise further in the future because of the technology to reduce secondary pollutants such as dioxins.

As mention above, the treatment of solid waste has become an utmost important in Japan, particularly the methods of high water content organic solid waste for recycle or energy recover are under development. There are mainly two methods to turn the high water content organic solid waste into recovering energy or recirculating resource: producing fuel technology (such as RDF) and resource recovery technology by biological treatment. The basic principle in the development of the later technology is the solubilization of organic solid waste and now is studied by many researchers. The degradation by high energy such as supercritical and subcritical water treatment (Goto et al., 1997), ozonation (Yasui et al., 1997), hot alkali treatment (Suzuki and Inagaki, 1994), 
biodegradable method by thermophilic bacteria (Hasegawa et al.,1997; Imaoka et al.,1998; Li and Noike, 1992; Liu and Mori, 1993) and physical treatment (Nawa, 1995) are in development.

This paper describes the solubilization of excess sludge by high speed rotary disk process. This method is a kind of physical treatment. The excess sludge from final sedimentation tank in wastewater treatment plant was used in this study. The objectives of this study are to improve the solubilization of excess sludge by grind and shearing force through high speed rotary disk process and to promote the solubilization of microorganisms due to the function of hydrolase from broken microbial cell.

\section{MATERIALS AND METHOD}

\section{Description of experimental apparatus}

The experimental apparatus used in this study is shown in Fig.1. Different concentrations of sludge were processed the experiments. The sludge samples $(10 \mathrm{~L}$ each) were input at the inlet of fixed upper disk. The samples were treated though the high rotary speed of lower disk. The treated samples flew out from the gap of disks and were collected, then recirculated for 25 or 50 times. It is possible to be cooled the treated samples, if the samples become high temperature due to many times of recirculation. The experiments were conducted with gaps between two disks of $200 \mu \mathrm{m}, 250 \mu \mathrm{m}$ and $500 \mu \mathrm{m}$, respectively, and rotating speed was set equivalent to 3500 r.p.m.
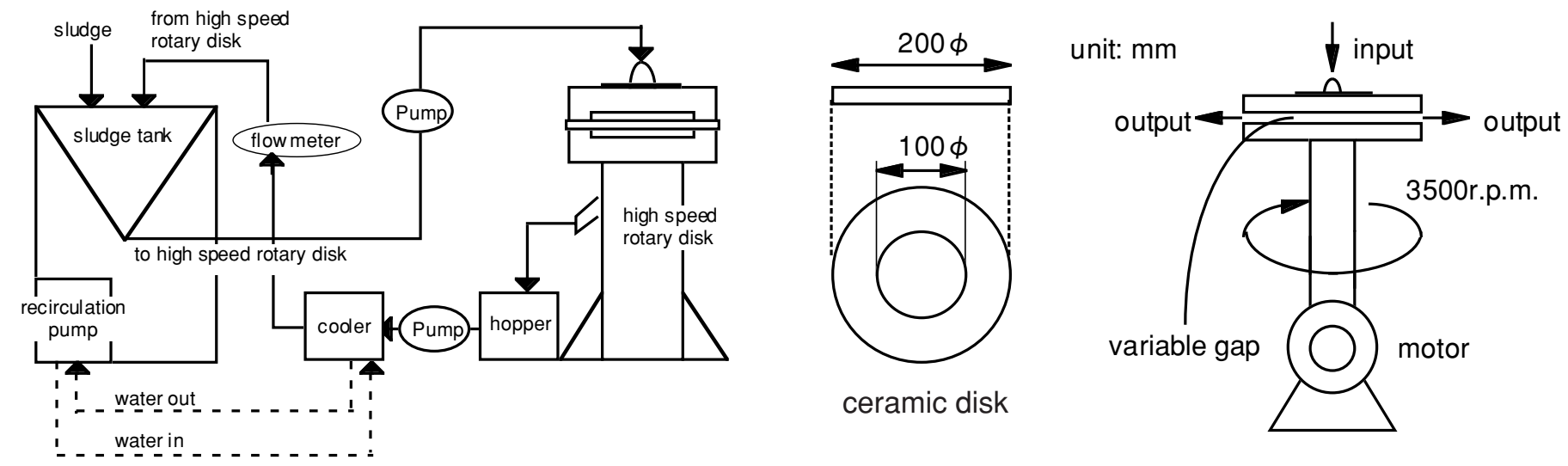

Fig.1 Experimental apparatus of high speed rotary disk.

\section{Experimental procedures}

In this study, it takes 1 minute for one recycle of sample. The relationships among the concentration of MLSS, recycle times and particle size distributions were investigated. The particle size distribution, soluble $\mathrm{BOD}_{5}$, DOC, MLSS and MLVSS were measured. In addition, samples after 25 times recycle treatment were stirred slowly at room temperature for 24 hours, then filtered through a $1.0 \mu \mathrm{m}$ filter, and filtered samples were analyzed for DOC measurement.

\section{Analytical method}

Dissolved organic carbon (DOC) concentration and Total organic carbon (TOC) in liquid samples were

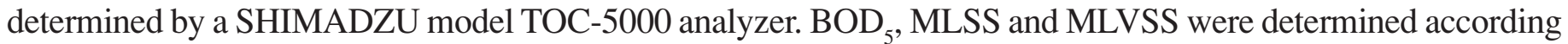
to Standard Methods (1992). Particle size distribution was analyzed by a Horiba model LA-920 analyzer. 


\section{RESULTS AND DISCUSSION}

\section{Relationships between recycle times and particle size distributions}

The relationship between recycle times and particle size distributions are shown in Fig.2. Four different concentrations of excess sludge (i.e. MLSS of 1300, 4700, 8800, and $11300 \mathrm{mg} / \mathrm{L}$ ) were used. The average particle size of samples was about $70 \mu \mathrm{m}$. The gap between two disks was set at $250 \mu \mathrm{m}$. After first time treatment, the particle size of sludge decreased rapidly to $20 \mu \mathrm{m}$. It seemed no significant change with the increase of recycle time and became relatively steady-state after 50 times recycle treatment with a particle size of $10 \mu \mathrm{m}$. There is no difference between 1 time treatment and 25 times treatment as shown in Photo.1 (MLSS $=4700 \mathrm{mg} / \mathrm{L}$ ). The median of particle size before treatment was about $70 \mu \mathrm{m}$ as shown in Fig.2. This might be due to the protozoa and fine sands. The floc of sludge had no influence on the particle size, and this was demonstrated by supersonic treatment test. The remarkable efficiency was observed in the first time treatment. This was probably due to the function of grind between two disks on the samples. However, it seemed no effect on bacteria because of their small size. On the other hand, the concentration of MLSS had no effect on the particle size of treated samples (50 times treatment) in this range of MLSS.

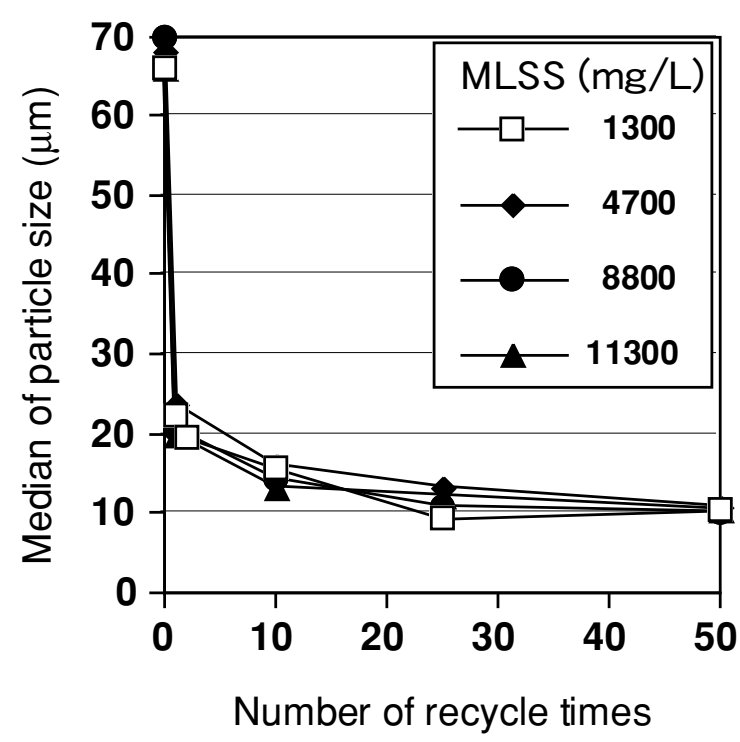

Fig.2 Relationships between recycle times and particle size distributions.

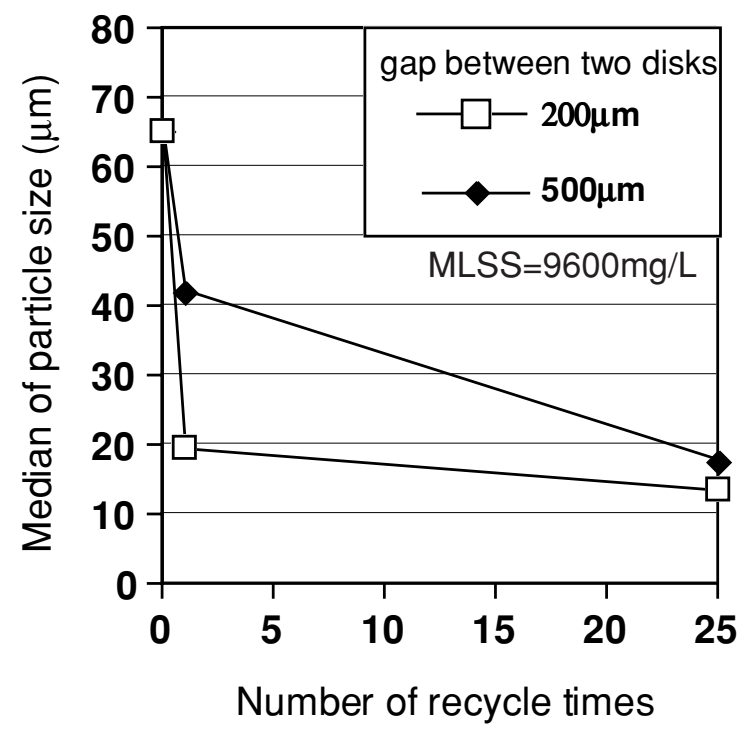

Fig.3 Relationships between disk gap, recycle times and particle size.
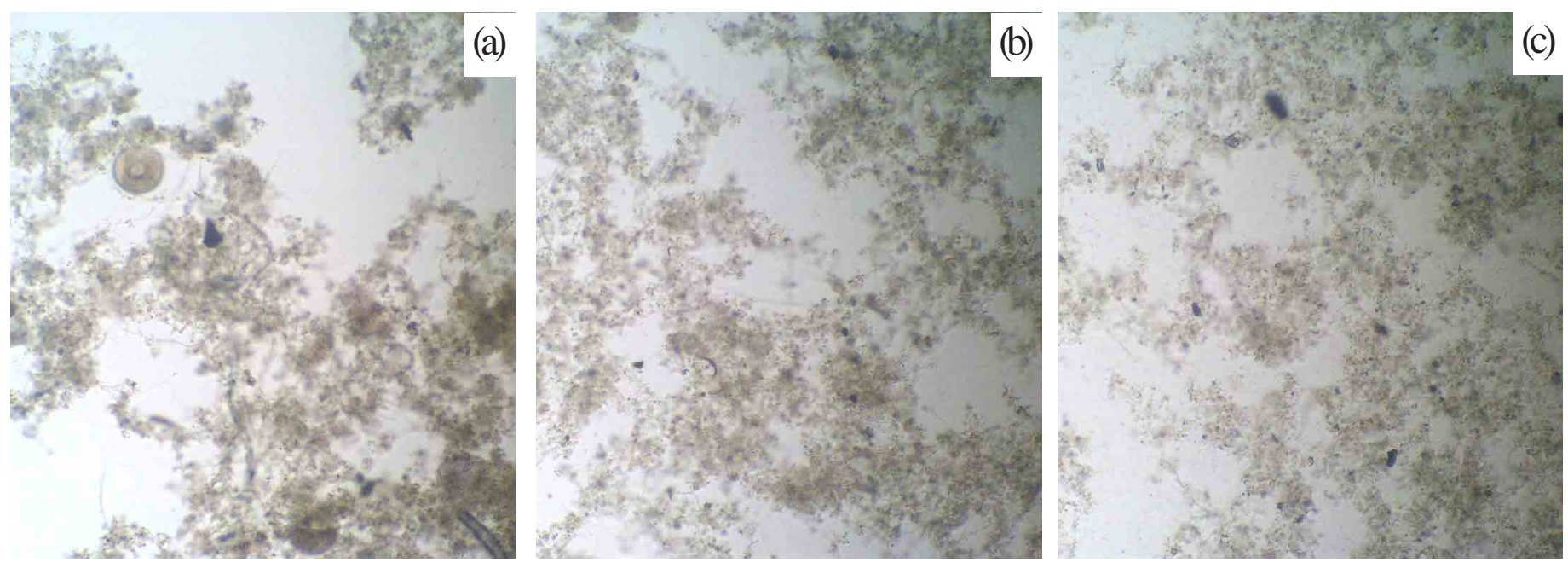

Photo.1 Microscopic photographs of excess sludge (MLSS=4700mg/L). (a)no treatment, (b)1 time recycle, (c) 25 times recycle 
The particle sizes of samples after treatment through two kinds of gaps $(200 \mu \mathrm{m}$ and $500 \mu \mathrm{m})$ were investigated, and the results are shown in Fig.3. After first time treatment, the particle size through small gap $(200 \mu \mathrm{m})$ decreased more than that through large gap $(500 \mu \mathrm{m})$. However, it seems no difference in size between these two operating conditions after 25 times treatment, and particle sizes become about $20 \mu \mathrm{m}$ in both conditions, that was a little larger compared with the results shown in Fig.2. This was probably due to the grinding loss of disk surface by fine sands in the samples.

\section{Relationships between recycle times and $\mathrm{BOD}_{5}$}

The changes of $\mathrm{BOD}_{5}$ concentration with the recycle times are shown in Fig.4. After 25 times treatment, $\mathrm{BOD}_{5}$ increased significantly, and it seems that there is an influence of recycle times on $\mathrm{BOD}_{5}$ concentration as compared with that of particle size. With the increase of recycle times, the $\mathrm{BOD}_{5}$ concentration was increased. For improvement of sludge solubilization, sludge treatment through small gap $(200 \mu \mathrm{m})$ is a little better than that through large gap $(500 \mu \mathrm{m})$. However, the balance between treatment efficiency and grinding loss of disks should be considered for the application of this process.

The changes of $\mathrm{BOD}_{5}$ with time after 25 times treatment stirred slowly at room temperature are shown in Fig.5. $\mathrm{BOD}_{5}$ concentration increased rapidly to $4000 \mathrm{mg} / \mathrm{L}$ during the initial 4 hours by disk treatment through 200 $\mu \mathrm{m}$ gap. Then it decreased quickly to $900 \mathrm{mg} / \mathrm{L}$. These phenomena of rapid increase of $\mathrm{BOD}_{5}$ in the initial period might be due to the following two reasons. Firstly, hydrolase solubilized through the break of cell, then high molecular organism hydrolyzed gradually to low molecular organism by enzyme function. Secondly, particle organism gradually hydrolyzed to low molecular organism. The rapid decrease of $\mathrm{BOD}_{5}$ was probably due to reuse of this readily degradable $\mathrm{BOD}_{5}$ as substrate by active (survival) biomass. After 24 hours, $\mathrm{BOD}_{5}$ concentrations in both operating conditions decreased to $1200 \mathrm{mg} / \mathrm{L}$. It was considered that a balance between the production of $\mathrm{BOD}_{5}$ by hydrolase and the consumption of $\mathrm{BOD}_{5}$ by active biomass. Therefore, the rapid increase of $\mathrm{BOD}_{5}$ during the initial period was likely due to hydrolyzation of fragment of cell by enzyme and active cells in lag-growth period. The rapid decrease of $\mathrm{BOD}_{5}$ after 4 hours was likely due to active cells in exponential-growth period and reused of solubilized $\mathrm{BOD}_{5}$ as substrate.

\section{Relationships between recycle times and DOC}

The relationship between the change of DOC and recycle times is shown in Fig.6. Even though the pattern of DOC change was almost the same with that of $\mathrm{BOD}_{5}$ after 25 recycle times through $200 \mu \mathrm{m}$ gap treatment. $\mathrm{DOC}$ concentration was only about a quarter of $\mathrm{BOD}_{5}$ concentration. The significant difference of the DOC

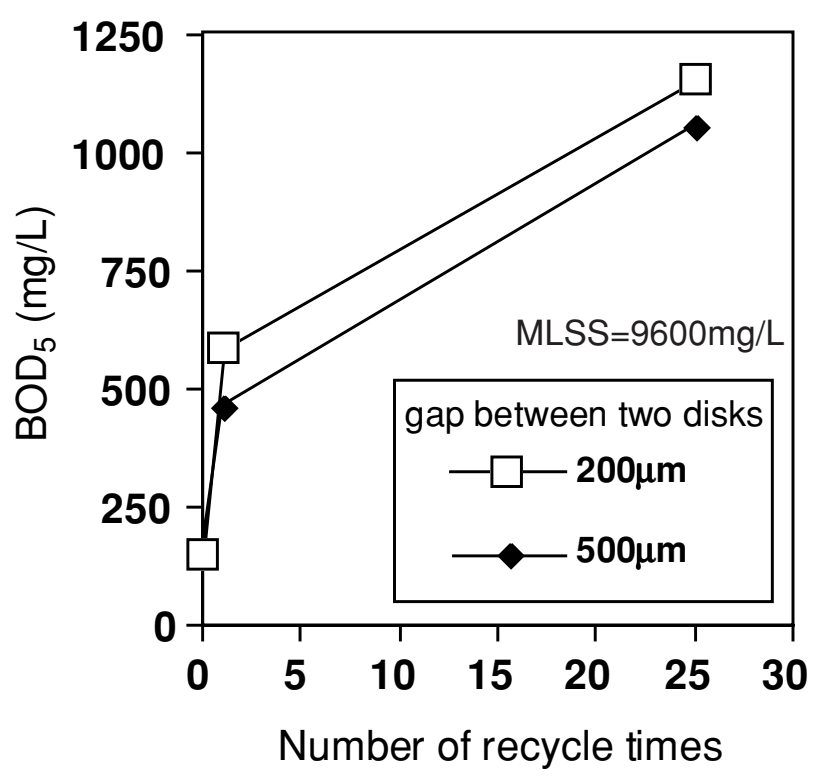

Fig.4 Relationships between recycle times and BOD concentration.

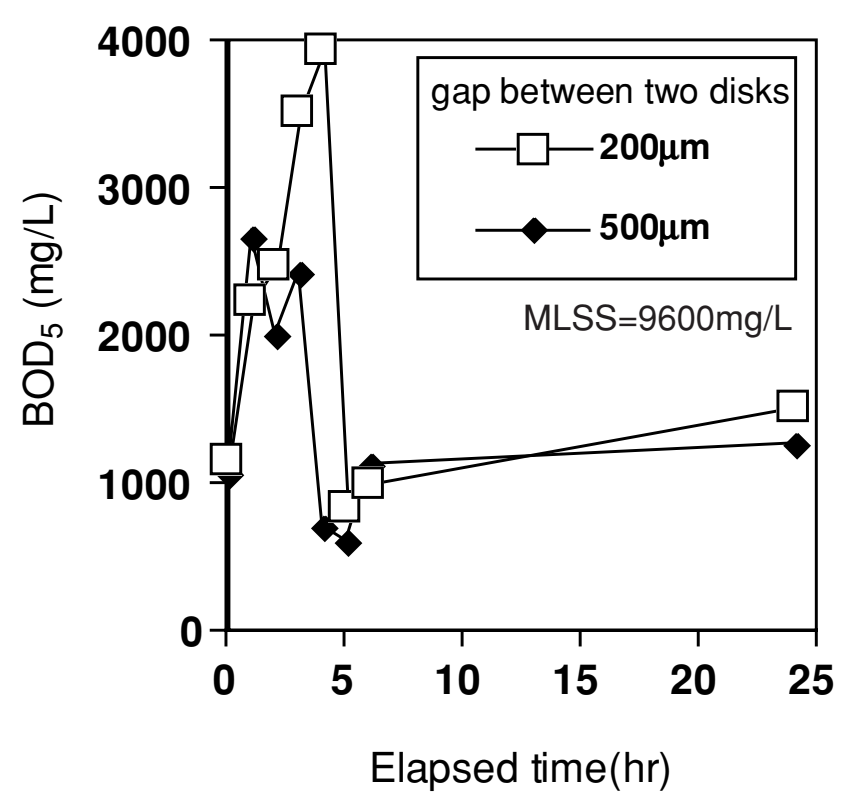

Fig.5 Changes of BOD concentration with time course. 


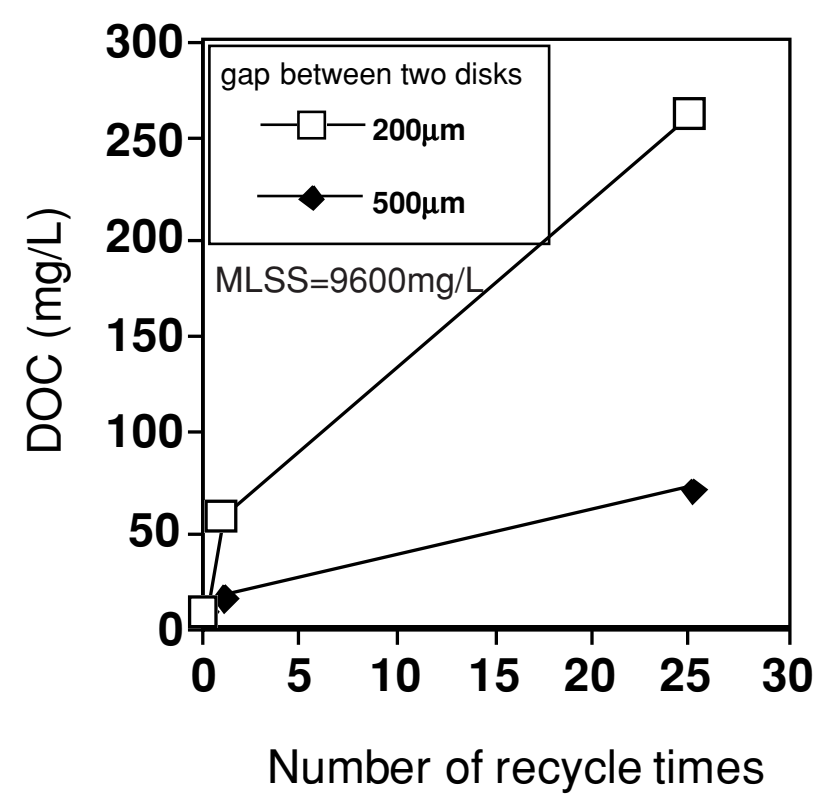

Fig.6 Relationships between recycle times and DOC concentration.

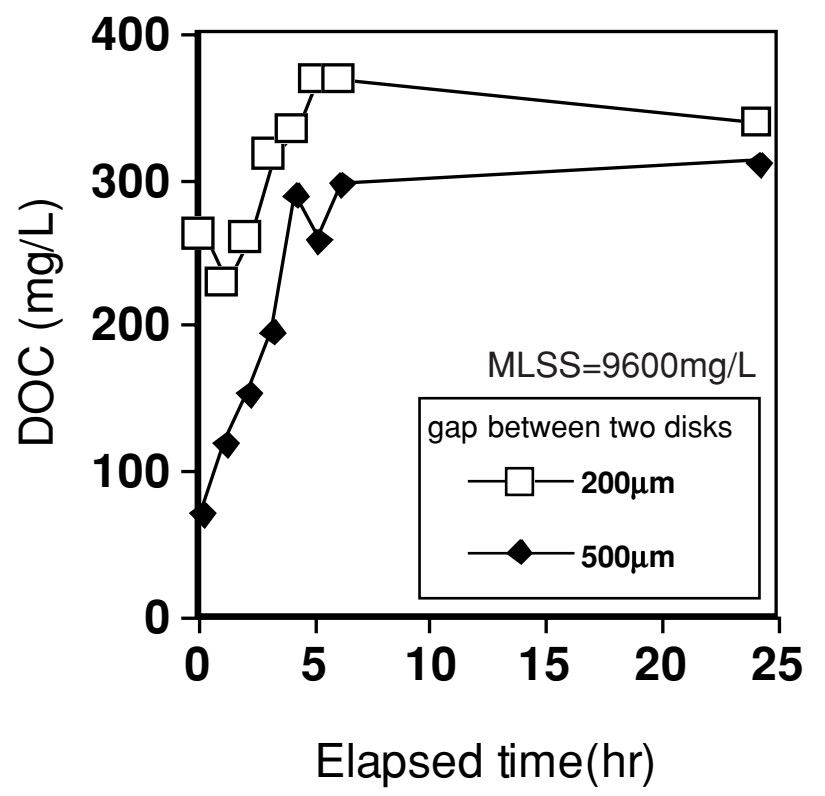

Fig.7 Changes of DOC concentration with time course.

Table 1 Classification of organic compound for the biodegradability.

\begin{tabular}{|c|c|c|c|}
\hline \multicolumn{2}{|c|}{ Dissolved organics } & \multicolumn{2}{c|}{ Suspended organics } \\
\hline $\begin{array}{c}\text { Biodegradable } \\
\text { organics }\end{array}$ & $\begin{array}{c}\text { Refractory } \\
\text { organics }\end{array}$ & $\begin{array}{c}\text { Biodegradable } \\
\text { organics }\end{array}$ & $\begin{array}{c}\text { Refractory } \\
\text { organics }\end{array}$ \\
\hline
\end{tabular}

values resulted from two gaps treatment was observed, and DOC values through small gap (200 $\mu \mathrm{m})$ treatment was about 4 fold than that of through large gap $(500 \mu \mathrm{m})$ treatment. It is supposed that increased quantity of soluble $\mathrm{BOD}_{5}$ through small gap compared with that through large gap was almost refractory organic matter.

The variation of DOC concentration with time after 25 times recycle treatment is shown in Fig.7. There seems to have the same trend as that of $\mathrm{BOD}_{5}$ during the initial 4 hours period. However, there was no rapid decrease of DOC concentration after 24 hours. This was considered that refractory organic matter existed most in soluble compositions. In addition, the rapid increase of $\mathrm{BOD}_{5}$ concentration during the initial 6 hours was the result of hydrolysis from suspended solids by comparison of the $\mathrm{BOD}_{5}$ results.

\section{Evaluation about definition of "solubilization"}

In this study, $\mathrm{BOD}_{5}$ and $\mathrm{DOC}$ were measured after the pretreatment of samples through $\mathrm{GF} / \mathrm{C}$ filter. However, at present there is no clear definition of "solubilization". If biodegradability of samples is used as explanation of solubilization, the definition of this basic standard should be necessary. From the view of the change of the ratio of readily biodegradable matter and slowly- biodegradable matter in soluble condition and suspended solid condition to explain the solubilization as shown in Table 1, the quantitative definition of the ratio should be demonstrated in the future study.

\section{CONCLUSIONS}

In this paper, the experiments of excess sludge through the gap of high speed rotary disk were carried out. The results showed that it was possible to improve the solubilization of sludge by grind and shearing force, and 
therefore to promote solution of lower molecular material from intracellular biomass. The following conclusions were drawn from the results of this study.

1. The particle size of sludge decreased rapidly after first time treatment, and it seemed no significant change of particle size of samples with the increase of recycle time. However, there was a great influence of recycle time on $\mathrm{BOD}_{5}$ concentration as compared with that of particle size, and the more the recycle time of treatment, the higher the function on $\mathrm{BOD}_{5}$ concentration improvement. The experiment indicated that it was possible to improve the solubilization of sludge by high speed rotary disk treatment process.

2. The increase of soluble organic component was a little higher than that through large gap. However, such small difference between both treatments supposed that refractory organic matter existed most in soluble compositions.

3. The rapid increase of $\mathrm{BOD}_{5}$ concentration during the initial 6 hours was considered to be the result of hydrolysis from suspended solids by comparison of $\mathrm{DOC}$ and $\mathrm{BOD}_{5}$ results.

4. The future research should be emphasized on the followings: 1) observation on the treatment of high concentration of sludge; 2) investigation of optimal operating condition; 3) extent of improvement of lower molecular through hydrolysis; 4) estimation of the existence of biomass; 5) exhaustion of disk in treatment of samples including high inorganic materials such as sand; 6) type of surface materials of disk.

\section{ACKNOWLEDGMENT}

The authors wish to thank Mr. Hirofumi NAGATA for his great cooperation and the TAKAHASHI Foundation for providing financial support in this study.

\section{REFERENCES}

Goto, M., Nada, T., Kawajiri, S., Kodama, A., and Hirose, T. (1997) Decomposition of municipal sludge by supercritical water oxidation. J. Chem. Eng. Japan, Vol.30, No.5, 813-818.

Hasegawa, S., Miura, M., Katsura, K. (1997) Solubilization of organic sewage by thermophilic bacteria. Journal of Japan Sewage Works Association, Vol.34, No.408, 76-82.

Imaoka, T., Hatano, K., Okada, M., Inoue, Y. (1998) Study of solubilization technology for converting biologically treated sludge to usable resources. Proceedings of the 32 nd Conference of Japan Society on Water Environment, Vol.32, 417.

Li, Y. Y., Noike, T. (1992) Upgrading of anaerobic digestion of waste activated sludge by thermal pretreatment. Water Science and Technology, Vol.26, No.314, 857-866.

Liu, B. G., Mori, T. (1993) Complete treatment of shochu processed wastewater by thermophilic oxic process. Environmental Engineering Research, Vol.30, 165-174.

Nawa, Y. (1995) Research on processes for increasing efficiency of anaerobic digestion, including mill pulverization process. Proceedings of 35th Sewerage Research Conference, Vol. 35, 852-854.

Standard Methods for the Examination of Water and Wastewater (1992). 18th edn, American Public Health Association/American Water Works Association/Water Environment Federation, Washington DC, USA.

Suzuki, T., Inagaki, T. (1994) Improvement of anaerobic sludge digestion process by hot alkali addition. Proceedings of 31 st Sewerage Research Conference, Vol. 31, 570-572.

Yasui, H., Shibata, M., Fukase, T. (1997) Acidic conditions minimize ozone dose on an activated sludge process without excess sludge production. Environmental Engineering Research, Vol.34, 211-220. 